\title{
Fundamental of a comparative treatment in rheumatoid arthritis: A brief review
}

\author{
Paramita Das*, C. Likhitha*, Anjali Nayak*, Ashwini Alur* and P. Padmavathi Prabhu** \\ *Department of Pharmacy, Krupanidhi College of Pharmacy, Chikkabellandur, Carmelaram Post, Varthur, Bangalore-560035, Karnataka, \\ India \\ **Department of Pharmacy, Srinivas College of Pharmacy, Valachil, Farangipete Post, Mangalore-574143, Karnataka, India
}

\section{Article Info}

Article history

Received 2 February 2021

Revised 23 March 2021

Accepted 25 March 2021

Published online 30 June 2021

\section{Keywords}

Rheumatoid arthritis

Inflammation

NSAID

Nanotherapy

Genetherapy

\begin{abstract}
Rheumatoid arthritis (RA) is a debilitating chronic systemic autoimmune inflammatory disease, a long term condition and affects 1-3\% of population worldwide that causes severe pain, inflamed bone erosion, unsteadiness, stiffness in the joints and deformity. It gradually deteriorates over the course of many years. The exact causes of RA are still unknown but genes, environmental factor, hormone, obesity, smoking; age may be involved in autoimmune development and progression. Pathophysiology of RA is usually due to synovial membrane inflammation, chemokine involvement leading to swollen joints. In the early hours, diagnosis and management can help to prevent damage to the joints. To understand the recent advances in physiology of RA, several biologics DMARDS include TNF-inhibitor, anti-CD20 antibody, IL-6 receptor antibody are implemented in current therapies and these advances are based on disease modifying therapy that includes with a goal where drug should reach targeted site and focused on pain relieving. Therapies are normally personalized with patients need including their general well-being. This review provides a modern appraisal from current literature on different RA treatment regimes.
\end{abstract}

\section{Introduction}

Rheumatoid arthritis (RA) is arising inflammatory asymptomatic disease, responsible for large amount of disability and morbidity. The second most common arthritis that affect world, the annual incidence of RA is approximately $1 \%$. RA initially affects symmetric polyarticular swelling of synovial, often tiny junction like hands, wrists including feet and could influence interior organs so give rise to everlasting disorder in numerous cases. The inflammation result in pain, stiffness and swelling causes disability and erosion of bone (Michelle et al., 2011). The onset of disease usually affects 35-60 years adult, with repeal and aggravation. In youngster, prior to age of 16 years referred to as juvenile RA, where rheumatoid arthritis factor is not detected. RA is a chronic syndrome that is progressive and destructive as compared to osteoarthritis (Bullock et al., 2018).

The design of therapy for RA exist to lower articulation swelling as well as affliction, maximize intersection role and stop joint demolition including disproportion therapy regimen consist of combination of medication, aerobics, teach victim regarding diseases, natura medication as well as recline. Therapies are normally personalized with patients need including their general well being (Najm, 2016).

\section{Corresponding author: Dr. Paramita Das}

Assistant Professor, Department of Pharmacy, Krupanidhi College of Pharmacy, Chikkabellandur, Carmelaram Post, Varthur, Bangalore560035, Karnataka, India

E-mail: paramitadas04@gmail.com

Tel.: +91-9742250412
This review provides a modern appraisal from current literature on different RA treatment regimes.

\subsection{History}

The word "Rheumatoid arthritis" is derived from Greek'Rheum' meaning that which flows and suffix 'oid' meaning like (Pouya Entezami et al., 2011). The earliest illustration of rheumatoid arthritis own before contemporary therapeutics established within thesis of Augustine Jacob Lander Beauvais from year 1800 and serve handful of cases with harsh rheumatism that are disqualified by other maladies to describe at the time such as "Rheumatism" or “osteoarthritis” Lawrence and Parish, (1963: Staff, 2012).

Alfred Garrod during $19^{\text {th }}$ century is earliest to discriminate gout from additional arthritis. Archibald Garrod $4^{\text {th }}$ son of Alfred Garrod over 1890, he authored a volume' treatise and rheumatoid arthritis 'and coined phrase RA (Lawrence and Parish, 1963).

\subsection{Etiology}

The exact causes of RA are still unknown but genes, environmental factor, hormone, obesity, smoking; age may be involved in autoimmune development and progression. Certain factors such as genetic especially human leukocyte antigen (HLA) class 2 genotype patients who are seropositive for anticitrullinated protein antibodies (ACPASs) or rheumatoid factor (RF) also have increased the risk of rheumatoid arthritis (Sana Bal, 2019).

Rheumatoid arthritis is conditions which involve 150 diseases usually progressive and relate with discomfort. Due to abnormality in cellular and humoral immunity leads to occurrence of antibodies like RF, ACPAS's, AMPA (anti-modified protein antibodies), a CarP 
(carbamylation), AAPA (acetylation) and also immigration of $\mathrm{T}$ and B-lymphocytes into synovium (Vander and Houwig, 2009).

The genome sequence such as protein tyrosine phosphate, nonreceptor type 22(PTPN22), increases risk for development of type-1 diabetics, RA and systemic lupus erythematous (Hammer, 1995). This is characterized by HLA-DRB 1 alleles (especially DR4 and DR1) that have 5 amino acid shared moti (QKRAA, QRRAA or RRRAA in positions 70-74 of DRB1 chain) which is encoded with positively charged $\mathrm{P} 4$ motif that known as shared epitope (Gregersen et al, 1987), HLA connect with 3 amino acid in beta chain of HLA-DR (11, 71 and 74), i.e., one in HLA-B and one in beta chain HLA-DPB1 are associate with RA (Raychaudhuri, 2012). The self-protein like P4 when modified, they interact with RF, ACPA and anti-CarbP antibodies reinforce T-cell activation leads to epitope spreading finally leads to clinical disease (Tarcsa et al., 1996).

\subsection{Epidemiology}

Epidemiology studies (www.who.int/chp/topics/rheumatic) suggest that rheumatism arise as long term intrinsic immunity disorders, stand up incessant in women than men (Qiang et al., 2018). The prevalence of rheumatism is $0.5 \%-1 \%$ in female and male. In age 30 to 60 lies in ratio of 3:1, i.e., 4 to 5 times high cases found in women less than 50 years but the ratio becomes approximately 2 to 1 after 60 years (Intriogo et al., 2019) Therefore, the life time risk development of RA is 3.6\% in women and $1.7 \%$ in men (Cynthia et al., 2011). Lupus erythematous is about $1-10^{\text {th }}$ common rheumatoid arthritis and common in especially in child bearing age (IngeMargretne et al., 2018). Lumbar vertebrae producing nerve irritation and ligamentous train result in low back pain affect commonly middle age men (Bao and Dai, 2011).

\section{Plant natural products used in RA}

Globally, plant based medicines are used for treatment of RA and achieved acceptance by wide-reaching capacity. Herbal products control inflammation through various pathway such as antiinflammatory mediator (IL-4 and IL-10), osteo-immune cross talk (bone is bidirectional) and treg balance (essential for immunological tolerance).

Trpterygium wilfordii Hook $F$ (TwHF) extract leads to suppression of COX-2 and reduces production of prostaglandin E2 (Tao et al., 1998 ) (Guo W et al., 2001). It targets the iNOS gene, i.e., inducible nitric oxide synthetase and increase blocks the production of nitric oxide (Makrygiannakis, 2008). In synovial fibroblast of human, TwHF augmenting tissue inhibitor of metalloproteinase (TIMPs) and block MMP1\&2, further blocks MMP 3. It suppresses numerous cytokine $(\mathrm{TNF} \alpha)$ from $\mathrm{T}$ cells. TwHF conquer T/B unit boost and synovial fibroblast extension also induce $\mathrm{T}$ cell death.

Curcuma longa is an Indian indigenous plant, curcumin a secondary metabolite potent bioactive molecule possess broad range of antirheumatoid effect (Zdrojewicz et al., 2017). In recent preclinical trials, curcumin shows effectiveness in treating arthritis by rat model and reduces extent of pro-inflammatory cytokines in serum as well as synovial fluids (Kim, 2008). It regulates COX and lipoxygenase enzyme, blocks various MMP 9 and MMP 13 and inhibit IL-1 $\beta$, mitogen activated protein kinase (MAPK), peripheral blood mononuclear cell (PBMCs) in RA patient.
Camellia sinesis (green tea) originated in China, widely used in Asia and possesses some anti-rheumatoid effect (Ramadan, 2017; Haqqi et al., 1999). Inducing green tea to AA rats reduced progression of arthritis and serum analysis shows reduced proinflammatory cytokine (TNF $\alpha$ and IL-1 $\beta$ ) in rats (Bhumtia Pemba et al., 2015). Epigallocatechin-3-gallate (EGCG), apolyphenol shows multiple inflammatory pathways (Hostetler GL et al., 2017). EGCG can hinder RA with inhibition of IL- 6 union and gesturing $\beta$-activated kinase (growth factor) in rat models. It shows increase in nuclear factor (Nrf2) and regulates indoleamine-2, 3 dioxegenase (IDO).

Flavanoids have been considered a powerful anti-inflammatory agent (Lee et al., 2009). A surplus film of hexane fragment obtained from Rhus verniciflua decreased secretion of TNFa, IL-6, IL-8, MCP-1, VEGF, p-ERK, p-JNK and up regulation of p-p38-MAPK in animal model (Park et al., 2016).

Reservatrol, a natural polyphenol potent antioxidant, antinflammatory agent obtained from stilbenes. In vitro studies of reservatrol shows decreased production of TNF- $\alpha$, IL-1 $\beta$ in monocytes / macrophages (Zou et al., 2013), inhibit T-cell activation; inhibit proliferation of fibroblast like synovicytes and decreased expression of MMP3 (Tian et al., 2013; Masso Gonzalez et al., 2010).

Boswellia serrata is used as ayurvedic medicine which includes chemical constituents like resin, terpinoid and oils. The extracts of this are used to treat chronic inflammatory disease (Kumar et al., 1999). It act by inducing IL-6 which intern synthesis SGPT, SGOT enzymes in body (Chatterjee and Pal, 1984) which has capacity to stabilize lysosomal enzyme activity like alkaline phosphatase (ALP) (Mishra, 2011).

Cinnamomum zeylanicum is a shrub found in Asia, Australia and India. They are well known for non-volatility where essential oils extracted by distillation (Senanayake et al., 1978). Type Aprocyanidine polyphenols extracted from cinnamon used in vitro in AIA rat model (Anderson et al., 2004). They act on C-reactive protein used in treating RA also found to be non-ulcerogenic and as no analgesic effect (Scott et al., 1994)

Zingiber officinale is a ancient traditional medicine as antiinflammatory effect and scientifically proved by Kiuchi in 1982 (Kiuchi, 1982). T-cell activity on vascular cellular adhension molecule (VCAM) in venules cause inflamed tissue (Feldmann and Steinman, 2005) where Zingiber officinale act by inhibiting prostaglandin and leukotriene biosynthesis catechol group of ginger played vital role which shows activity against 5-lipoxygenase (Thomson et al., 2002).

Artemisia capillaris contains scoparone as major component, extracted using hot water (Barnes and Karin, 1997). When administered orally to mouse induce arachidonic acid and inhibit PGE2, iNOS, COX-2, TNF- $\alpha$ and stimulate macrophage (Kwon, 2011).

Coriandrum sativum (CS) is a perennial herb used in traditional system of medicine to treat RA (Evans, 2006). It is a potent antioxidant used in in vitro testing system (Krishnakantha and Lokesh, 1993). The anti-inflammatory activity is not clear whether CS contributes to antiarthritic activity or act as adjuvant for principle drug (Li et al., 2008). Though, it is difficult to see activity of CS, the steroidal compounds present in high concentration in seeds are responsible for antiarthritic effect (Gupta et al., 1980). 
Jasminum lanceolarium is a traditional Chinese medicine (Wen et al., 2015). The stems and roots are used to treat RA which act by inhibiting membrane hydrolysis of membrane phospholipids which is involved in COX-2 production inhibit PGs (Sengar et al., 2015)

Hibiscuss platnifoliu is or species of a flowering tree, found in regions like India and Srilanka. It includes many active principle components like citric, tartaric and oxalic acid, sterol, cholesterol, fructose, glucose, sucrose, etc., which shows antiarthritic activity similar to aspirin (Paval et al., 2009).

Capsicum annum is a very popular antiarthritic remedy used both among local population and specialists practicing traditional medicine (Meghvansi et al., 2010). It interns reduce edema, decreases amount of alpa-1-acid glycoprotein in blood which mainly act by reducing the severity of non-specific inflammation (Setarch et al., 2018).

Table 1: Various plants used for the treatment of RA ( Himanshu et al., 2019)

\begin{tabular}{|c|c|c|c|c|c|}
\hline Plant name & Family & Constituents & Target & Inhibition & Action \\
\hline $\begin{array}{l}\text { Trpterygium wilfordii } \\
\text { Hook F. }\end{array}$ & Celastraceae & Triptolide, Celastrol & iNOS gene & $\begin{array}{l}\text { MMP1, MMP2, } \\
\text { MMP3 }\end{array}$ & Potent Anti-inflammator \\
\hline Curcuma Longa & Zingiberaceae & $\begin{array}{l}\text { Curcumin, Demethoxy } \\
\text { curcumin, Bis } \\
\text { demethoxy curcumin }\end{array}$ & $\begin{array}{l}\text { Lipoxygenae } \\
\text { enzyme }\end{array}$ & $\begin{array}{l}\text { MMP9, MMP13, } \\
\text { MAPK, PBMC's } \\
\text { and IL-1 } \beta\end{array}$ & $\begin{array}{l}\text { Antidepressant } \\
\text { Antioxidant }\end{array}$ \\
\hline Camellia sinesis & Theaceae & $\begin{array}{l}\text { Catechin, Epicatechin, } \\
\text { Gallic acid }\end{array}$ & $\begin{array}{l}\text { T-lymphocytes } \\
\text { TH-17 kinase }\end{array}$ & $\begin{array}{l}\text { IL-6, IL-17 } \\
\text { B-activated }\end{array}$ & $\begin{array}{l}\text { Antibacterial, Antiviral } \\
\text { activity in vitro }\end{array}$ \\
\hline Cissampelos pareira & Menispermaceae & $\begin{array}{l}\text { Dicentrine, 5-Deoxy- } \\
\text { inostiol }\end{array}$ & $\begin{array}{l}\text { TH-1 } \\
\text { Phenotype }\end{array}$ & $\begin{array}{l}\text { Macrophage, } \\
\text { TNF- } \alpha, \text { IL- } 6 \text {, } \\
\text { IFN- } \beta\end{array}$ & Analgesic, Antidiarrhea \\
\hline Flavanoids & Zingerberaceae & Flavonol, Anthocyanin & $\begin{array}{l}\text { Lipid and Gly- } \\
\text { cogen enzyme }\end{array}$ & $\begin{array}{l}\text { PI3K, MAPK, } \\
\text { NFאB }\end{array}$ & Antagonistic effect \\
\hline Reservatrol & Bacillus cereus & $\begin{array}{l}\text { Stilbenetriol, Resorcinol, } \\
\text { Benzene-1, 3-diol }\end{array}$ & $\begin{array}{l}\text { Oxidative } \\
\text { DNA damage }\end{array}$ & $\begin{array}{l}\text { T-cell activation, } \\
\text { Nuclear factor }-\kappa b \\
\text { ligang }\end{array}$ & $\begin{array}{l}\text { Cardioprotective, Prevent } \\
\text { ageing }\end{array}$ \\
\hline Alpinia galanga & Zingiberaceae & Galangin, Beta-sitosterol & $\begin{array}{l}\text { Human } \\
\text { Chonddrocyte } \\
\end{array}$ & $\begin{array}{l}\text { IL-1 } \beta, \text { MMP-2, } \\
\text { MMP-9 }\end{array}$ & $\begin{array}{l}\text { CNS Stimulant, } \\
\text { Antimicrobial }\end{array}$ \\
\hline Glycyrrhiza glabra & Fabaceae & Glycyrrhizin, Glabridin & COX/TAX-2 & $\begin{array}{l}\text { Glutathione }(\mathrm{GSH}) \\
\text { expression }\end{array}$ & $\begin{array}{l}\text { Hepatoprotective, } \\
\text { Anticancer, } \\
\text { Antiinflammatory }\end{array}$ \\
\hline Moringa oleifera & Moringaceae & $\begin{array}{l}\text { Kaempferol, } \\
\text { Chlorogenic acid, } \\
\text { Isothiocyanate }\end{array}$ & $\begin{array}{l}\text { iNOS gene, } \\
\text { COX-2 }\end{array}$ & $\begin{array}{l}\text { TNF- } \alpha, \text { IL- } \beta \text {, } \\
\text { IL-6 }\end{array}$ & $\begin{array}{l}\text { Regulate enzyme } \\
\text { activity, Modulate } \\
\text { blood glucose }\end{array}$ \\
\hline Piper longum & Piperaceae & $\begin{array}{l}\text { Piperine, Chavicine, } \\
\text { Piper longuminine }\end{array}$ & $\begin{array}{l}\text { IL- } 1 \beta \text { stimulated } \\
\text { fibroblast }\end{array}$ & $\begin{array}{l}\text { PGE2,IL-6, } \\
\text { MMP's }\end{array}$ & $\begin{array}{l}\text { Antimalaria, Antiasthma, } \\
\text { Antigonorrhea }\end{array}$ \\
\hline Aloe vera & Lillaceae & $\begin{array}{l}\text { Barbaloin derivatives } \\
\text { and resin }\end{array}$ & Growth factor & $\begin{array}{l}\text { PGE2, } \\
\text { Neutrophil } \\
\end{array}$ & Purgative \\
\hline Papaver somniferum & Papaveraceae & Morphine, Codeine & $\begin{array}{l}\text { Brain and Spinal } \\
\text { cord recptor }\end{array}$ & $\begin{array}{l}\text { NF } \kappa \mathrm{B}, \mathrm{TRPV} \\
1 \mathrm{COX}-2, \mathrm{PGE} 2\end{array}$ & Analgesic, Narcotic \\
\hline Catharanthus roseus & Apocynaceae & Vincristine, Vinblastin & Immune cells & $\begin{array}{l}\text { Anterograde } \\
\text { and Retrograde } \\
\text { Axonal transport }\end{array}$ & Antileukaemic, Anticancer \\
\hline
\end{tabular}

\subsection{Abbreviation}

iNOS, Induced Nitric oxide Synthase; MMP-1, Metaloproteinase1; MMP-2, Metaloproteinase-2; MMP-9,Metaloproteinase-9; MMP-13, Metaloproteinase-13; MAPK, Mitogen Activated Protein Kinase; PBMC's, Peripheral Blood Mononuclear Cell; IL-1 $\beta$, Interleukin-1 $\beta$; IL-6, Interleukin-6; IL-17, Interleukin-17; IFN-Ò, Interferon-Ò; PI3K, Phosphatidylinositol-3-kinase; NFאB, Nuclear Factor Kappa-Chain-Enhancer of Activated B-cells; TNF- $\alpha$, Tumor Necrosis Factor- $\alpha$; TH-17, Helper cell T-17; COX-2, Cyclooxy- genase-2; PGE2, Prostaglandin; VEGF, Vascular Endothelial Growth Factor; TRPV1, Transient Receptor Potential Vanilloid-1.

\section{Convential drugs used in RA}

Non-steroid anti-inflammatory drugs (NSAID's) help to lower the chronic pain, redness as well as swelling, thereby decreasing pain and improve function. They classified based on individual chemical structure, plasma half-life including cyclooxygenase. Commonly used class of NASID's drugs are acetyl salicylic acid, indomethacin, ketorolac, oxaprozin, ketoprofen, meclofenamate, phenlbutazone, 
piroxicam, celecoxin, etoricoxib, lumaricoxib etc., are first line therapy. NSAID's based on plasma half-life tend to assemble in junction of joints remain shorter in plasma (Capone et al., 2010). Drugs with half-life more than $12 \mathrm{~h}$. increases the plasma levels but remain constant between doses. The second isoform (COX2) is isoenzymes likely be important factor, express induced stimuli and result increased synthesis of PGs in neoplastic tissues. Specific pharmacologic factor associated with NASID's, might affect irregularity related to dose response, plasma half life, enantiomer change, secrete void as well as pharmacodynamics variations.

Today, prednisone is suggested at squat dose in RA and work as substitution therapy (Hinz and Brune, 2007). The exogenous synthetic glucocorticoids exerts a selected action, possess distinct plasma kinetic, metabolism and biologic half-life (mom-genomic at high dose compared to hydrocortisone). In long period, glucocorticoids may hinder with hypothalamus-pituitary-adrenal (HPA) function and effect endogenous cortisol production. In the era 1980-2004, long term glucocorticoid therapy was used, in former decade an ongoing depletion of mean initial low dose from 10.3 to $3.6 \mathrm{mg} / \mathrm{day}$ (prednisone) (Pincus et al., 2015) was prescribed.

3.1 Non biological disease modifying anti-rheumatoid drugs (DMARDs)

The non biological disease modifying anti-rheumatoid drugs (DMARDs) used in combination with low dose of glucocorticoids recommended for management of RA (Singh et al., 2016). In early morning hours, RA symptoms are maximum exaggerated, proinflammatory cytokines is relatively better to treat habitual signs in morning (Cutolo et al., 2005; Buttgereit et al., 2015). By accurate chronotherapy, many inflammatory pathways relating central nervous system, increase sleep quality and reduce depressive symptoms. Lot of research shows altered liberation of prednisone possesses healthier-efficacy for long term. Low dose glucocorticoid management shows a remarkable cutback in forenoon joint rigidity yet without any auxiliary repression of HPA axis (Hypothalamicpituitary-adrenal axis) (Buttgereit et al., 2010; Atten et al., 2015).

\subsection{Biological DMARD's}

Biological DMARDs are suggested later to find break down after use of one or more standard DMARDs treatment. These are incompetent in mixture with one and all; trials are in progress to assess risk including satisfaction of combination therapy (Statkute and Ruderman, 2010). Biologic DMARDs drugs are infliximab, adulimumab, etanercept, golimumab and cetrolizumab. These biologics are efficient as monotherapy and satisfy in distant reaction and blockage of radiographic progression whether used in coexistence with a methotrexate (Breedveld et al., 2006).

Rituximab be illusive anti-CD20 monoclonal antibody used in RA and B-cell non-Hodgkin's lymphoma. In placebo controlled trials of rituximab showed slow radiographic progression with methotrexate after a year of treatment (Furst et al., 2007; Kevstone et al., 2009). Anakinra has accepted as a second line of therapy, is an IL-1 receptor antagonist is recommended with methotrexate as daily dose and shown improvement in patient function.

Tocilizumab is a recombinant humanized monoclonal antibody that binds to IL-6 receptor. Monthly infusion of tocilizumab refine consequence and standards of patient who meet cut out control of accepted DMARD' or anti-TNF therapy (Emery et al., 2008; Old et al., 2009).

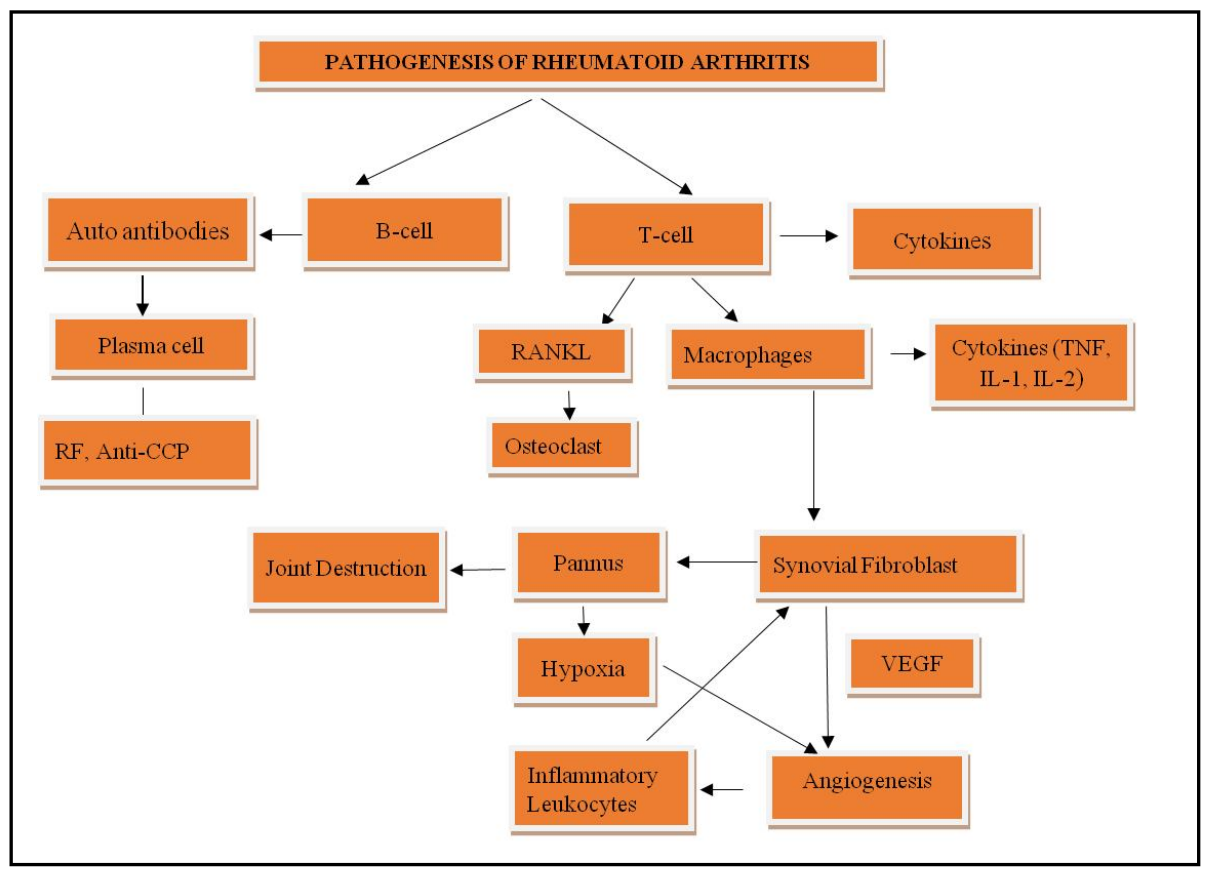

Figure 1: Pathogenis of RA; Inflammation in RA is due to activation of B-cells and T-cells. Activated in synovium leads macrophages activation and pro-inflammatory cytokines such as TNF- $\alpha$, IL-1 $\beta$ and IL-6 cause joint damage this futher leads to increased MMP's production and activates osetoclast. TNF- $\alpha$, IL-1 $\beta$ and IL-6 due to over production forms pannus which induce state of relative hypoxia and promote angiogenesis thus pannus invade into cartilage and bone leading to joint destruction. Production of vascular endothelial growth factor (VEGF) stimulate angiogenesis that identifies inflammation recruting more inflammatory leukocytes. (Branimir, 2014). 


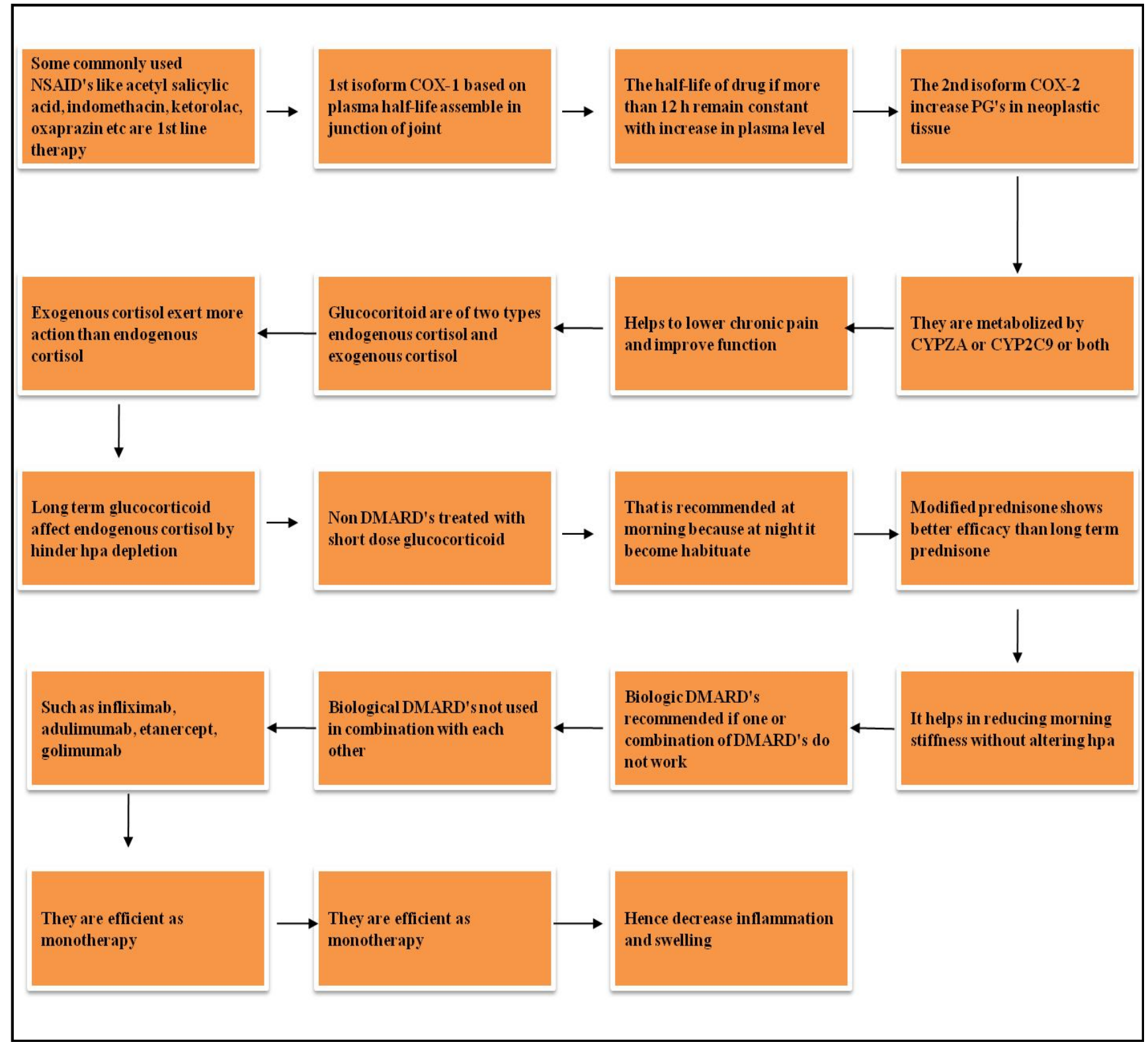

Flow chart 1: Various treatment used in RA.

\section{Nanotherapy in RA}

Nanotherapy is highly striking as diagnostic agents, the targeted nanocarrier sustained drug delivery system in RA increase solubility of certain drugs and protect them against degradation in circulation, further increase bioavailability and reduce unwanted off-target side effect (Christine, 2011). The anti-inflammatory therapeutics are quite toxic in both inflamed cell and normal cell, however, implementing passive and active targets of anti-inflammatory drugs in to nanoparticles can improve specificity of inflamed cell and tissue (Kapoor et al., 2014; Yang et al ., 2017). Nanotechnology enables redesign of already effective rheumatologic medications in to nanoformulation that confer better specificity long therapeutic effect and safe profile such as nanoencapsulated NASID's, liposomal and polymeric preparation of glucocorticoids and nanosystem that directly inhibit angiogenesis are considered as nanotherapies (Jasenka, 2019). To improve specificity and efficacy, nanoparticles like micells and liposome mixed with an antibody, peptide or polysaccharide (act on specific receptor) reduce unwanted toxicity and side effect. Nanoparticles permeate through endothelial cell of synovial tissue and retained in extravascular space releases drug slowly, improved permeability and retention (Metselaar et al., 2004; Hofkens et al., 2011)

Folic acid with albumin nanoparticles used to enhance specific in an in vitro model methotrexate with PLGA nanoparticles against macrophage specific receptor CD64 are effective than free drug in treating RA (Moura et al., 2014). The folic acid targeted PLGA nanoparticles significantly increase cellular uptake of dexamethasone in activated macrophage and decrease production of proinflamma- 
tory cytokinase (TNF- $\alpha$, IL-1, IL-6) and nitric oxide from activated macrophage (Put et al., 2013). Folic acid with albumin nanoparticles used to enhance specific delivery of etoricoxib also showed remarkable success in delivery of etoricoxib in tissue sac of inflamed joint compared to free drug and non-targeted nanoparticles due to strong affinity of folic acid (Gerlag et al., 2001).

Table 2: Conventional classification of target carriered RA drugs

\begin{tabular}{|l|l|l|l|l|l|}
\hline Classification & \multicolumn{1}{|c|}{ Drugs } & \multicolumn{1}{c|}{ Carriers } & \multicolumn{1}{c|}{ Size } & \multicolumn{1}{c|}{ Target } & \multicolumn{1}{c|}{ Refrences } \\
\hline NASID's & $\begin{array}{l}\text { Indomethacin } \\
\text { Aceclofenac }\end{array}$ & $\begin{array}{l}\text { Polymericmiscellies } \\
\text { Lysine-liposomes }\end{array}$ & $\begin{array}{l}\text { 240 } \\
-\end{array}$ & $\begin{array}{l}\text { EPR } \\
\text { EPR }\end{array}$ & $\begin{array}{l}\text { (Bernardi } \text { et al., 2009) } \\
\text { (Sharma } \text { et al., 2017) }\end{array}$ \\
\hline Glucocorticoid & $\begin{array}{l}\text { Dexamethasone } \\
\text { Methylprednisone }\end{array}$ & $\begin{array}{l}\text { Liposomes } \\
\text { Cyclodextrin polymeric }\end{array}$ & $\begin{array}{l}96 \\
27\end{array}$ & $\begin{array}{l}\text { EPR } \\
\text { EPR }\end{array}$ & $\begin{array}{l}\text { (Quan } \text { et al., 2014) } \\
\text { (Hwang } \text { et al., 2008) }\end{array}$ \\
\hline DMARD's & Methotrexate & $\begin{array}{l}\text { Stealth-type polymeric } \\
\text { Liposomes }\end{array}$ & $\begin{array}{l}51-116 \\
120-160\end{array}$ & $\begin{array}{l}\text { EPR } \\
\text { Macrophages }\end{array}$ & $\begin{array}{l}\text { (Ishihara } \text { et al., 2009) } \\
\text { (Barrera } \text { et al., 2000) }\end{array}$ \\
\hline $\begin{array}{l}\text { BIOLOGIC } \\
\text { DMARD's }\end{array}$ & $\begin{array}{l}\text { Etanercept } \\
\text { Anakinra }\end{array}$ & $\begin{array}{l}\text { TMN Complex } \\
\text { Folate-chitosan DNA }\end{array}$ & $\begin{array}{l}250 \\
110\end{array}$ & $\begin{array}{l}\text { EPR } \\
\text { Macrophages }\end{array}$ & $\begin{array}{l}\text { (Jung } \text { et al., 2012) } \\
\text { (Femand } \text { et al., 2018) }\end{array}$ \\
\hline
\end{tabular}

Abbrevation: Enhanced permeability and retention (EPR)

Flow chart 2: Nanotherapy used in RA.

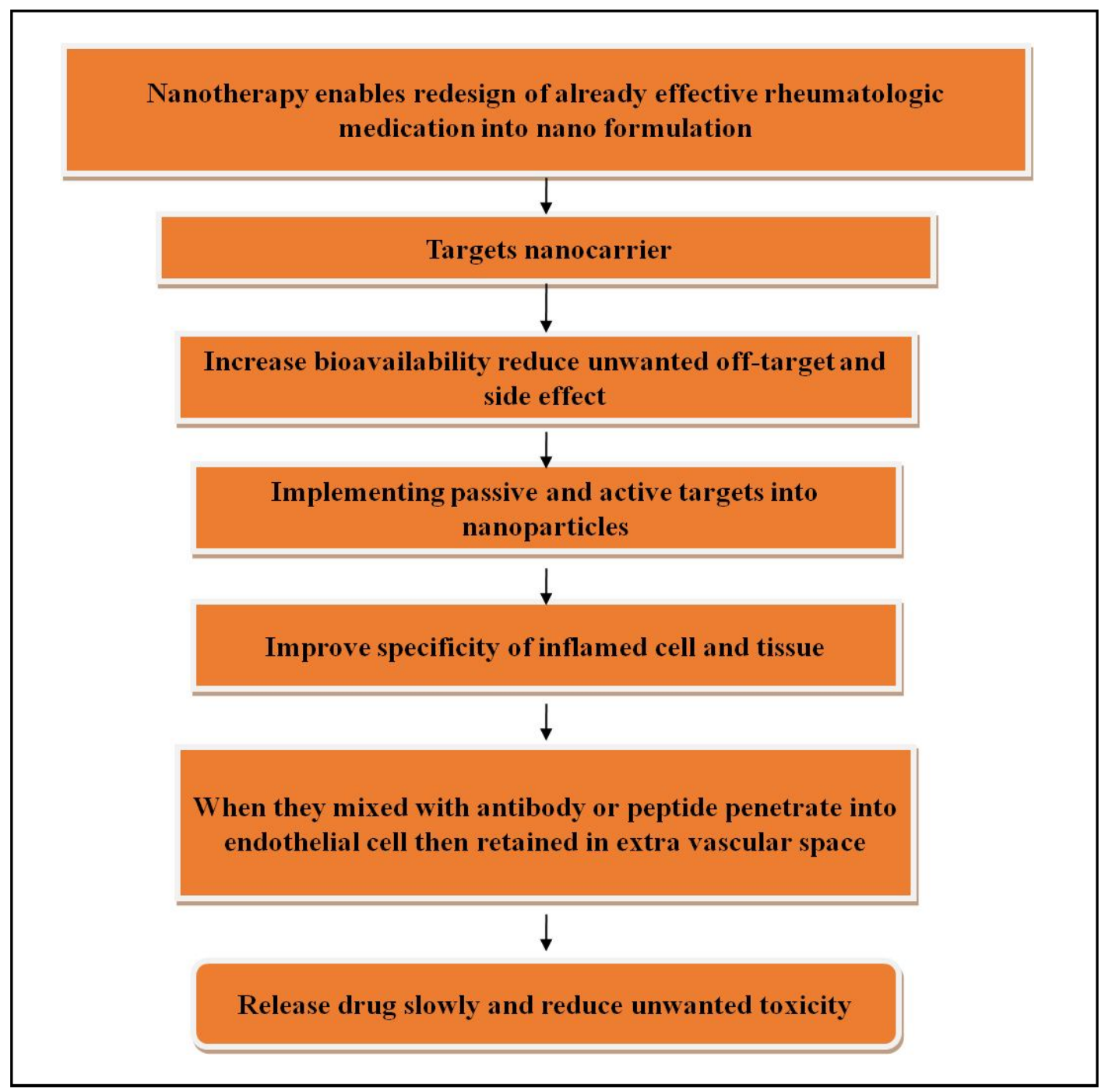




\section{Chemotherapy in RA}

In numerous studies showed development of rheumatologic symptoms in patients include those with lung cancer, ovarian cancer, and Hodgkin's lymphoma as well as patients with hematologic malignancies (Amir and Jaferian, 2012). Slow acting anti-RA drugs (SAARD's) help slowly the progression and reduce joint damage and other serious complication. Some studies showed depletion in sequence of erosion is temporary with gold, sulphasalazine, cyclophosphamide and methotrexate but aggregate work cut out to convey notable affect of SAARD's working as radiologic progress (Scott et al., 1983; Spector Seoff, 1988). Chemotherapy treatment for RA involves DMARD's take medication from of pill, injection or intravenous infusion. RA chemotherapy often involves a combination therapy to improve the efficacy and minimize side effect (Elizabeth Hanes, 2019; Schwarzer et al., 1990). The patient with multiple myeloma treated with melphalan, dexamethasone with allopurinol in chemotherapy regimen. Numerous rheumatologists forsaken the conventional therapeutic pyramid or undo this with stand down overpass appeal of combination in disease control.

\section{Nutraceuticals (Food extracts)}

Nutraceutical are a blend of nutritional supplements and pharmaceutical medication and its outcome change in c-reactive protein (CRP), seromucoids, fibrinogen, TNF- $\alpha$, prostaglandin E2, oxidative stress, erythrocyte sedimentation rate (ESR), antioxidant status (Sahar and Al-Akbi, 2012). Some of the nutraceuticals phenolic compound, polyunsaturated fatty acid, phytosterols and carotenoids used in joint pathology includes glucosamine, chondroitin, fish oil, capsaicin, turmeric, etc. (Vista and Lau, 2014). Glucosamine is a key component in biosynthesis of prostaglandin and inhibits activity of catabolic enzyme such as phospholipase A2, aggrecanases then reduce regulated IL-1 level in synovial fluid (Chan et al., 2006; Calamia et al., 2010).

Chondroitin sulphate controls high level of proteogly, thus help preventing inflammation and break down of joint cartilage (Uebelhart et al., 1998). Topical capsaicin acts in the skin and causes hypersensitivity and also activates nonneuronal TRPV1 which release IL-8, IL-6, PGE2, thus reduces by a process defuntionalization of nociception (Masoumeh et al., 2019). Fish oil contains omega-3-fatty acid which is natural anti-inflammatory mediator which helps in slow blood cloting and decreases joint tenderness and morning stiffness (Bethany, 2015).

\section{Gene therapy in RA}

Gene transfer may be alternative approach targeted sustain delivery of inhibitor of inflammatory cytokinines. Recently gene therapy for RA has entered clinical trials. TNF- $\alpha$ inhibition playd vital role in gene therapy, either single or combination gene therapy, TNF- $\alpha$ is found at high level in synovial fluid of patients with RA (Tak et $a l .$, 1997). Hence, TNF- $\alpha$ blockade result in amelioration of joint destruction and local expression of anti-TNF- $\alpha$ single chain antibody blocks disease development which is observed in mice with CIA (Smith et al., 2003). Because of complex pathology combination of TNF- $\alpha$ and IL- 1 blockade by adenoviral gene therapy in rabbits is more effective than cytokines alone (Ghivizzani et al., 2001). Using this approach, it is possible to obtain $20 \%$ improvement in about $60-70 \%$ of RA patients (Flendrie et al., 2005).
Inhibition of NFKB activation which is highly activated in synovium and as ability to induce pro-inflammatory mediators like cytokines and inducible nitric oxide which also act as protecting factor of synovial cell from apoptosis (Didonato et al., 1997). Hence, NFkB inhibition increase synovial cell apoptosis in RA patients so phosphorylation inhibition of $\kappa \mathrm{B}(\mathrm{I} \kappa \mathrm{B})$ protein is a major step in

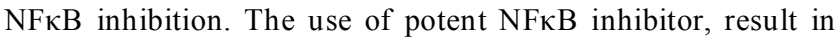
decrease joint swelling in mice with CIA (Gerlag DM et al., 2000). Treatment for RA patient in NFKB inhibition also had done by over expression of I $\mathrm{B} \alpha$ in human synovial tissue reduces production of pro-inflammatory cytokines without affecting antiinflammatory mediators (Miagkov et al., 1998).

\section{Conclusion}

Taken together, in last decades a major revolution has seen in treatment of RA patients. The current treatment principle includes symptomatic management and disease modification. NSAIDs can be recommended for RA patients for immediate relief of pain, swelling and stiffness of joint at risk of adverse effects. DMARDs therapies appear to be both patient and physical dependent. Early treatment with DMARDs can retard disease progression more efficiently but decreases ability to fight infection. Biological DMARDs are with fast onset of action and high. Rate of responses but interfere with immune system and increase risk for infection. Herbal medicines outcome are inconsistent, so can be used as complimentary medicines. Curcuma longa and TwHF have most clinical evidence to treat RA. Further defining mechanism of action and significant validation of plant products will be more widely accepted. Nanotherapy is designed to improve the therapeutic properties and ensure controlled release of drugs. Despite the increasing number of new drugs, complete long term remission is not achieved. A new retroviral mediated adoptive cellular gene therapy is used for RA. The main challenge in gene therapy is to provide cost effective long term safe treatment.

In conclusion, new combined improved therapeutic approach will dramatically improve the current therapeutic outcomes.

\section{Acknowledgments}

We would like to thanks Principal and management of Krupanidhi College of Pharmacy, Bangalore for their support and encouragement.

\section{Conflict of interest}

The authors declare that there are no conflicts of interest relevant to this article.

\section{References}

Amiri, A.H. and Jaferian, S. (2012). Post-chemotherapy arthralgia and arthritis in lung cancer. South. Asian. J. Canc., 1(2);72-75.

Atten, R.; Grahn, A. and Holt, R.J. (2015). Delayed release prednisone improve fatigue and health related quality of life findings from CAPRA-2 double blind randomised study in RA.1:e00134.

Anderson, R.A.; Broadhurst,; C.L. and Polansky, M.M. (2004). Isolation and characterization of polyphenol type-A polymers from cinnamon with insulin-like biological activity. J. Agri. Food Chem., 52:65-70

Bader, R.A. The Development of Target Drug Delivery System For RA Treatment. http://www.intechopen.com/ 
Bao, J. and Dai S.M. (2011). A chinese herb, Tripterygium wilfordii hook of in the treatment of rheumatoid arthritis mechanism efficacy and safety., Rheum., 31:1123-1129.

Barnes, P. J. and Karin, M. (1997). Nuclear factor-kappaB; a pivotal transcription factor in chronic inflammatory diseases. N. Engl. J. Med., 336:1066-1071.

Barrera, P.; Blom, A.; Van, P.L.; Van, B.L.; Beijnen, J.H.; Van,N.D.; Waal, M.C.; Van de P.L.B.; Strom, G. and Vanden, B.W.B. (2000). Synovial macrophages depletion with dodronate containing liposomes in rheumatoid arthritis. Arth. Rheum., 43:1951-1959.

Bethany, Afshar (2015). 11 Herbs and supplements for RA to take or avoid.

Bhumtia, P.H.; Sharangi, A.B.; Lepcha, R. and Tamang, D. (2015). Bioactive compounds and antioxidants properties of tea: Status, global Research and Potentialities. J. Tea. Sci. Res., 5:1-13.

Bernardi,A.; Zilbersyein. A.C.; Jager, E.; Campos, M.M.; Morrone, F.; Pohlmann, A.R.; Guterres, S.S. and Battastini, A.M. (2009). Effect of indomethacin loaded nanocapsules effect in experimental models of inflammation in rats. Britain J. Pharmacol., 158:1104-111.

Breedveld, F.C.; Weisman, M.H. and Kavanaugh, F. (2006). The premier study: A multicenter randamized double blind clinical trial of combination therapy with adalimumab plus methotrexate verus methotrexate alone or adalimumab alone in patients with early aggressive RA who had not had previous methotrexate treatment. Arthritis. Rheum., 54:26.

Bullock, J.; Rizvia, A.; Saleh, A.M. and Ahmed, S. (2018). Brief overview of treatment RA. Med. Princ. Prac., 27:501-507.

Buttgereit, F.; Smolen, J.S. and Wogan, A.N. (2015). Clocking in chronobiology in RA. Nat. Rev. Rheumatology., 11:349-356.

Buttgereit, F.; Doering, G. and Schaeffler A. (2010). Targeting pathophysiological rhythms prednisone chronotherapy shows sustained efficacy in RA. Annals. Rheum. Dis., 69:1275-1280.

Calamia, V.; Ruiz, R.C.; Rocha, B.; Fernandez, P.P, Montell, E.; Verges, J. and Blanco, F.J. (2010). Pharmacoproteomic study of effect of chondroitin and glucosamine sulfate on human articular chondrocytes., Art. Res. and Ther., 13:138.

Chan, P.S.; Caron. J.P. and Orth, M.W. (2006). Short term gene expression changes in cartilage explants stimulated with interleukin beta plus glucosamine and chondroitin sulfate. J. Rheum., 33:1329-1340.

Capone, M.L.; Tacconelli, S.; Rodriguez, L.G. and Patrignani. (2010). NASID's and cardiovasculardisease transducing .result into clinical read out in general population. Pharmacology Rep., 15:530-535.

Chatterjee, G. and Pal S. (1984). Anti-inflammatory agents from Indian medicinal plants. Indian Drugs, 21:431.

Christine, T.N. (2011). Nanotherapeutic approaches for treatment of rheumatoid arthritis. Wiley Interdisciplinary Rev. Nanomed. Nanobiotech., 12:3(6).

Cutolo, M.; Otsak, K. and Aakre, O. (2005). Nocturnal hormones and clinical rhythms in RA. Annals of New York Academy of Sciences, 1051:372-381.

Cynthia, M.S.; Eric L.M. and Elena, M. (2011). The life time risk of adult onset rheumatoid arthritis and inflammatory autoimmune rheumatoid disease. Arth. Rheu., 63:633-639.

Di, D. J. A.; Hayakawa, M.; Rothwarf, D.M.; Zandi, E. and Karin, M. (1997). A cytokine-responsive ikappaB kinase that activates the transcription factor NF-kappaB. Nature. 388:548-554.

Evans, W.C. (2006). Volatile oil and resin. In: Evans W C, Editor, Trease and Evans Pharmacog. New Delhi: Elesevier, pp:262.
Emery, P.; Keystone, E. and Tony, H.P. (2008). IL-6 receptor inhibition with tocilizumab improves treatment outcome in patients with RA refractory to antitumor necrosis factor biologics. result from a 24 week multicenter randomized placebo-controlled trial. Annals of the Rheumatic Diseases. 67:1516.

Feldmann, M. and Steinman, L. (2005). Design of effective immunotherapy for human autoimmunity. Nature, 435(7042):612-619.

Furst, D.E.; Breedveld, F.C. and Kalden, J.R. (2007). Updated consensus statement on biological agent for treatment of rheumatic disease. Annals. of the Rheumatic Dis., 66(3):112.

Femandes, J.C.; Wang, H.; Jrey, S.C.; Benderdour, M.; Lavigne, P.; Qiu, X.; Winnik, F.M.; Zhang, X. and Dai, K.S. (2008). Bone protective effect of nonviral gene therapy with folate-chitosen DNA nanoparticle containing interleukin-1 receptor antagonist gene in rats with adjuvantinduced arthritis. Mol. Ther., 16:1243-1251.

Flendrie, M.; Creemers, M.C.; Welsing, P.M. and Van, R.P.L. (2005). The influence of previous and concomitant leflunomide on the efficacy and safety of infliximab therapy in patients with rheumatoid arthritis; a longitudinal observational study, Rheumatology. 44:472-480.

Furst, D.E.; Breedveld, F.C. and Kalden, J.R. (2007). Updated consensus statement on biological agent for treatment of rheumatic disease. Annals of the Rheumatic Dis., 66(3):112.

Gerlag, D.M.; Borges, E. and Tak, P.P. (2001). Suppresion of murine collagen induced arthritis by targeted apoptosis of synoival neovasculature. Arth. Res. and Ther. 3:357-361.

Gerlag, D.M.; Ransone, L. and Tak, P.P. (2000). The effect of a T cell-specific $\mathrm{NF}-\mathrm{kappa} \mathrm{b}$ inhibitor on in vitro cytokine production and collageninduced arthritis. J. Immunology, 165:1652-1658.

Ghivizzani, S.C.; Oligino. T.J.; Glorioso, J.C.; Robbins. P.D. and Evans. C.H. (2001). Direct gene delivery strategies for the treatment of rheumatoid arthritis. Drug Discovery Today, 6:259-267.

Gregersen, P.K.; Silver, J. and Winchester, R.J.; (1987). The shared epitope hypothesis. An approach to understanding the molecular genetics of susceptibility to rheumatoid arthritis. Arth. Rheum., 30:12051213.

Gupta, M.B.; Nath, R.; Srivastava, N.; Shanker, K.; Kishor, K. and Bhargava, K.P.; (1980). Antiinflammatory and antipyretic activities of Bsitosterol. Planta. Medica., 39:157-63.

Guo, W.; Ma, L. and Tao, X.; (2001). In vitro inhibitive effects of Triypterygium wilforii on no production, inos activity and iNOSmrna expression in chondrocytes of patients with rheumatoid arthritis. Arth. Rheum., 44:2193-2200.

Hammer, J.; Gallazzi, F.; Bono, E.; Karr, R.W. and Guenot, J.V.P. (1995). Peptide binding specificity of HLA-DR4 molecules:correlation with rheumatoid arthritis association. J. Exp. Med., 181:1847-1855.

Haqqi, TM.; Anthony, D.D.; Gupta, S.; Ahmad, N.; Lee, M.S.; Kumar, G.K. and Mukhtar, H.; (1999). Prevention of collegen-induced arthritis in mice by a polyphenol fraction from green tea. Procceding of the National Academy Science USA, 96:4524-4529.

Hinz, B. and Brune, K. (2007). Antipyretic, analgesic nonsteroidal antiinflammatory drug, selective cox-2 inhibitors, paracetamol and pyrazolinone. Hand. Exp. Pharmacol., 15:65-93.

Hostetler, G.L.; Ralston, R.A. and Schwartz, J. (2017). Flavones: Food source, bioactivity advance in nutrition. Int. Rev. J., 8(3):423-435.

Hofkens, W.; Storm, G.; Vanden, W.B. and Van, L.P.L. (2011). Liposomal targeting of gluco-corticoids to the inflamed synovium inhibit cartilage martix distrubution during murine antigen induced arthritis .Internaitional Journal of Pharmacy, 416:486-492. 
Hwang, J.; Rodgers, K.; Oliver, J.C. and Schluep, T. (2008). Alpha-methy prednisone conjugated cyclodextrin polymers based nanoparticles for rheumatoid arthritis therapy. Int. J. Nanomed., 3:359-371.

Intriogo, M.; Maldonado, G. and Cardenas, J.R.; (2019). Clinical characteristic in patient with rheumatoid arthritis. Scientific World J., 1-6.

Inge-Margretne, G.; Torek, K.; Glenn, H. and Gunnar, H.; (2018). Bone mineral density in systemic lupus erythematous. Ann. Rheum. Dis., 14:299.

Ishihara, T.; Kubota, T.; Choi, T. and Higati, M. (2009). Treatment of experimental arthritis with stealth type polymeric nanoparticles encapsulating betamethasone phosphate. J. Pharmacol. Exp. Ther., 329:412-417.

Jasenka, P. Z. (2019). Nanotherapies for rheumatoid arthritis. Nano. Lubes. Nov., pp:15.

Jung, Y.S. and Park, W.N.K. (2012). Temperature modulated nanocovalent interaction controllable complex for the long term delivery of etanercept to treat rheumatoid arthritis. J. Cont. Release, 171: 143-151.

Kapoor, B.; Singh, S.K.; Gulati, M.; Gupta, R. and Vaidya, Y.(2014). Application of liposomes in treatment of Rheumatoid Arthritis. Scientific World J., 1:1-17

Kim, H.R.; Rajaiah, R.; Wu, Q.L.; Saypute, S.R.; Tan, M.T.; Simon, J.E.; Berman B.M. and Moudgil, K.D. (2008). Green tea protects rats against autoimmune arthritis by modulating disease-related immune events. J. Nut., 138:2111-2116.

Kiuchi, F.; Shibuya, Kiuchi, F.; Shibuya, M. and Sankawa. U. (1982). Inhibitor of prostaglandin biosynthesis from ginger, Chem. Pharma. Bulletin., 30(2);754-757.

Krishnakantha, T. and Lokesh, B.R. (1993). Scavenging of superoxide anions by spice principles. Indian. J. Biochem. Biophys., 30:133-140.

Kumar, V.; Cotran, R.; and Robbins, S. (1993). Basic pathophysiology 6th edition, pp:44-45.

Kwon, O.S. (2011). Inhibition of 5-lipoxygenase and skin inflammation by the aerial parts of Artemisia capillaries and its constituents. Arch. Pharm. Res., 34:1561-1569.

Lawrence, C. and Parish A.B; (1963). An historical approach to the nom enclature of rheumatoid arthritis. Arthritis and Rheumatism, 6:60-61.

Lee, J.D.; Huh J.E.; Jeon, G.; Yang, H.R.; Woo, H.S.; Choi D.Y. and Park, D.S. (2009). Flavanol rich RVHXR from Rhus verniciflua stoke and its major compound fisten inhibits inflammation related cytokines and angiogenic factor in ra fibroblast like synovial cells and in vivo model. Int. Imm. Pharmacol., 9:268-276.

Li, R.; Li, J.; Cai, L.; Hu, C.M. and Zhang, L. (2008). Suppression of adjuvant arthritis by hesperidin in rats and its mechanisms. J. Pharma. Pharmacol., 60:221-228.

Makrygiannakis. D.; Hermanson, M.; Ulfgren A.K.; Nicholas A.P.; Zendman, A.J. Eklund A.; Grunewald, J.; Skold, C.M. and Catrina, A.I.; (2008). Smoking Increase peptidylarginine deminase 2 enzyme expression in human lungs and increase citrullation in BAL cells. Annals of Rheumtic Diseases., 67:1488-1492.

Masoumeh, S.; Roshanak S.; Houshang R.Y.R.; Houshang, R.; Yalda, R.; Danial, Z.; and Maryam, S. (2019). Skin inflammatory reaction to capsaicin in RA patients compared to healthy control. Avicenna J. Phytomed., 9(1):54-61.

Masso Gonzalez, E.L.; Patrignani, P.; Tacconelli, S. and Garcia Rodriguez, L.; (2010). Variability among non-steroidal anti-inflammatory drug in risk of upper gastrointestinal bleeding. Arthritis. Rheumtology, 15:1592-1601.
Miagkov, A.V.; Kovalenko, D.V. and Brown, C.E. (1998). NF-kappa B activation provides the potential link between inflammation and hyperplasia in the arthritic joint. Procceeding of the National Academy Sciences USA, 95:13859-64.

Metselaar, J.M.; Vanden, B.W.B.; Holthuysen, A.E.; Wauben, M.H.; Storm, G. and Van, L.P.L. (2004). Liposomal targeting of gluco-corticoids to synovial lining cell. strongly increase therapeutic benefit in collagen type- 2 arthritis. Annals of the Rheumatic Diseases, 63:348-353.

Moura, C.C.; Segundo, M.A.; Das, N. J.; Reis, S. and Sarmento, B. (2014). Coassociation of methotrexate and SPION's into anti-CD64 antibody conjugated PLGA nanoparticles for therapeutic application. Int. J. Nanomed., 9(1):4911-4922.

Meghvansi, M.K.; Siddiqui, S.; Khan, H.; Gupta, V.K. and Naga, C. (2010). A potential source of capsaicinoids with broad-spectrum ethnopharmacological applications. J. Ethnopharmac., 132:1-14.

Michelle, J.; Kahlenberg, M.D. and David A.Fax.; (2011). Advances in medical treatment of rheumatoid arthritis. Hand Clinics, 27(1):11-20.

Najm H (2016). Current treatment in rheumatoid arthrritis. Rev. Clin. Med., 7:6-14.

Old, F.V.; Dhillon, S. and Flosker, G.L. (2009). A review of its uses in management of rheumatoid arthritis drugs. Wolters Kulwer Health, Auckland, New Zealand, 69:609

Park, S.Y.; Lee, S.W.; Kim, H.V.; Lee S.V.; Lee, W.S. and Hong, K.W. (2016). SIRT inhibits differentiation of monocytes to macrophages amelioration of synovial inflammation in RA. J. Mol. Med., 94:921-31.

Paval, I.; Kaitheri, S.K. and Poutu. (2009). Antiarthritic potential of the plant Justicia gendarussa Burm F. Clinics (Sao Paulo), 64(4):357362 .

Pouya, Entezami, B.; David, F.M.D.; Phileips, Clapham, B.S. and Kivinc Chung, M.D. (2011). Historical perspective on etiology of rheumatoid arthritis. Hand Clinics, 27(1):1-10.

Pincus, T.; Sokka T. and Cutolo M. (2015). The past versus the present 19802004; Reduction of mean initial low dose long term glucocorticoid therapy in RA from 10.3 to $3.6 \mathrm{mg} /$ day concomitant with early methotrexate with long term effectiveness and safety of less than $5 \mathrm{mg} /$ day. Neuro. Immunomodulation, 22:89-103.

Put, S.; Schoonooghe, S. and Devoogat, N. (2013). SPECT imaging of joint inflammation with nanobodies targeting the macrophages mannose receptor in mouse model of rheumatoid arthritis. J. Nuc. Med., 54:807-814.

Qiang, Guo.; Yuxiang, W.J.N. and Nathan, J. (2018). Pathological mechanism and modern pharmacologic therapies. Bone. Res., 6:15.

Quan, L.; Zhang, Y.; Crielaard, J.; Dusad, A.; Lele, S.M.; Rijcker, C.J.F.; Metselaar, J.M.; Kostkova, H.; Etrych, T. and Ulbrich K. ( 2014). Nanomedicine for inflammatory arthritis head-to-head comparison of glucocorticoid containing polymers, miscelles and liposomes. Acc Nanomedicine, 8:458-466.

Ramadan, G.; EL-Beih, N.M.; Talaat, R.M.; and EL-Ghffar E.A. (2017). Antiinflammatory activity of green versus black tea aqueous extract in a rat model of human rheumatoid arthritis. Int. J. Rheu. Diseases, 20:203-213.

Raychaudhuri, S.; Sandor, C.; Stahl E.A.; Freudenberg, J.L.H. and Jia, X. (2012). Five amino acid sin three HLA proteins explain most of the association between MHC and seropositive rheumatoid arthritis. Nat. Gen., 44:291-296.

Sahar, Y. and Al-okbi. (2012). Nutraceuticals of anti-inflammatory therapy for activity as complementary therapy for rheumatoid arthritis. Toxicology and Industrial Health, 2008. 
Sharma, G.; Saini, M.K.; Thakur, K.; Kapil, N.; Garg, N.K.; Raza, K.; Goni, V.G. Pareek A. and Katare, O.P. (2017). Aceclofenac co-crystal nanoliposomes for rheumatoid arthritis with better dermatokinetic attributes a preclinical study. Nanomedicine, 12:615-638.

Sana, Bal. and Mohammad, A.R.S. (2019). Rev. Rheum. Arthritis., U.A. Pharm., 44:8-11.

Scott, D.L.; Coutton, B.L.; Chapman. J.H.; Bacon, P.A. and Popert, A.J. (1983) Thelong term effect of treating rheumatoid arthritis. JR Cell Physicians Lond., 17:78-88

Scott, D.T.; Lam,; F.M. and Ferrell, W.R. (1994). Acute join inflammationmechanisms and mediators. Gen. Pharmacol., 25:1285-1296.

Schwarzer, A.C.; Arnold, M.H. and Kelly. D. (1990). Cycling combination antirheumatoid arthritis drug therapy in rheumatoid arthritis., Brit. J. Rheum., 33:131-9.

Singh, J.A.; Saag KG.; and Bridges, S.L.; (2016). American College of Rheumatology Guidelines For Treatment of RA . Arthritis. Rheum., 68:1-26.

Statkute, L. and Ruderman, E.M. (2010). Novel TNF antagonists for treatment of RA. Expert In Investing Drugs, 19:105.

Senanayake U.M.; Lee T.H. and Wills, R.B.H. (1978). Volatile constituents of cinnamon oils. J. Agric. Food. Chem., 26(4):822-824.

Sengar, N.; Joshi, A.; Prasad, S.K. and Hemalatha, S. (2014). Anti-inflammatory, analgesic and anti-pyretic activities of standardized roo extract of Jasminium samba, J. Ethnopharmacol., 160:140-8.

Setareh, S.; Razavi, M.B. and Hossein, H.(2018) A review of the effects of Capsicum annuum L. and its constituent, capsaicin, in metabolic syndrome. Iran. J. Basic Med. Sci., 21(5):439-448.

Smith, R., Tarner, I.H. and Hollenhorst, M.; (2003). Localized expression of an anti-TNF single-chain antibody revents development of collagen-induced arthritis. Gene Thereapy, 10:1248-1257.

Spector, T.D. and Scott, D.L. (1988). What happens to patients with RA? The long term outcome of treatment. Clin. Rheum., 15:615-9.

Staff. (2012). Why did rheumatoid arthritis begin in 1800 . The Rheumatologist.
Tak, P.P, Smeets, T.J. and Daha. M.R. (1997). Analysis of the synovial cell infiltrate in early rheumatoid synovial tissue in relation to local disease activity. Arth. Rheum., 40:217-225.

Tarcsa, E.; Marekov, L.N.; Mei, J.; Melino, G.; Lee, S.C. and Steinert P.M. (1996). Protein unfolding by peptidyl arginine deiminase. J. Bio. Chem., 271:30709-30716.

Tao, X.; Schulze, K.H.; Mal, L.; Cai J.; Mao, Y. and Lipsky, P.E. (1998). Effects of Tripteryguim wilfordii hook $\mathrm{f}$ extracts on induction of cyclooxygenase 2 activities and prostaglandin E2 production. Arth. Rheum., 41:130-138.

Thomson, M.; Al-Qattan, K.K.; Al-Sawan, S.M.; Alnaqeeb, M.A.; Khan, I. and Ali, M. (2002), The use of ginger (Zingiber officinale Rosc.) as a potential anti-inflammatory and antithrombotic agent. Prostaglandins Leukotrienes and Essential Fatty Acids, 67(6);475-478.

Tian, J.; J-WC.; Gao, J.S.; Li, L. and Xie X. (2013). Resveratrol inhibits TNF$\alpha$ induced IL-1 $\beta$, MMP-3 production in human RA fibroblast Like synoviocytes via modulation of PI3 kinase/AKT pathway. Rheumatol Int., 33:1829-1835.

Uebelhart, D.; Thonar, E.J.; Zhang, J. and Williams, J.M. (1998). Protective effect of exogenous chondroitin 4, 6-sulfate in acute degradation of articular cartilage in rabbit. Osteoarthritis Cartilage, 6:6-13.

Vander, D.W. and Houwing, J.J. (2009). Quantitative heritability of anticitrullinated protein antibody positive and anti-citrullinated protein antibody-negative rheumatoid arthritis. Arth. Rheum., 60:916-923

Vista, E.S. and Lau, C.S. (2014). What about supplements for osteoarthritis: A critical and evidenced based review. Int. J. Rheum. Dis., pp: $152-158$.

Wen, X.N.; Jian, H.Z.; YI, Z.; Meng, D.L. and Dan, Y. (2015). Anti-inflammatory activity studies on the stems and roots of Jasminum lanceolarium Roxb. J. Ethnopharmacol., 171:335-1341.

Yang, M.; Feng, X.; Ding, J.; Chang, F. and Chen, X (2017). Nanotheraputics relive rheumatoid arthritis. J. Cont. Rel., 252:108-129. 